\title{
Maria no Brasil contemporâneo: libertadora, carismática e pop
}

\author{
Rodrigo Portella*
}

\section{Resumo}

$\mathrm{O}$ artigo pretende visualizar alguns rostos que a Virgem Maria tem assumido no Brasil nos últimos 40 anos. Para tal objetivo, fez-se o seguinte recorte: Maria na teologia da libertação; Maria na renovação carismática católica. Como adendo, também faz-se breve análise de Maria na cultura pop, análise que, neste caso, extrapola as fronteiras nacionais. É pretendido, portanto, apresentar como as sensibilidades teológicas e eclesiais contemporâneas, particularmente no Brasil, têm interpretado, simbolicamente, a figura de Maria, tanto no interior da Igreja Católica (os dois primeiros casos) como fora dela. Pelos limites impostos a um artigo, discute-se, aqui, apenas alguns casos específicos que, entretanto, poderiam servir como paradigmas. A metodologia é baseada na ciência da religião em diálogo com a teologia, e na análise de material devocional literário, musical e iconológico. A partir desta metodologia e do material utilizado na pesquisa, é compreendido que a fé católica, em suas expressões populares e, também, teológicas, busca, contemporaneamente, a interpretação sobre Maria ancorada em sensibilidades que, logicamente, em muito devem aos contextos sociais, políticos, econômicos e culturais em que está inserida.

Palavras-chave: Maria. Igreja Católica. Cultura pop. Movimentos eclesiais.

\section{Mary in contemporary Brazil: liberating, charismatic and pop}

\section{Abstract}

The article want to see some faces that the Virgin Mary has taken in Brazil in the last 40 years. For this purpose, we made the next cut: Mary in the theology of liberation; Mary in the Catholic charismatic renewal. As an addendum, also makes brief Maria analysis in pop culture analysis in this case goes beyond the national borders. It is intended, therefore, present as contemporary theological and ecclesial sensibilities, particularly in Brazil, have interpreted symbolically, the figure of Mary, both within the Catholic Church (the first two cases) and beyond. The limits imposed an article, we discuss here only a few specific cases, however, could serve as paradigms. The methodology is based

* Doutor em Ciência da Religião (pós-doutoramento PUC-Rio e Universidade do Minho). Professor Adjunto IV no PPCIR-UFJF. 
on the science of religion in dialogue with theology, and analysis of literary devotional material, musical and iconological. From this methodology and the material used in research, it is understood that the Catholic faith in its popular expressions and also theological, search, contemporaneously, the interpretation of Maria anchored at sensitivities, of course, much must the social, political, economic and cultural in which it operates. Key-words: Mary. Catholic church. Pop culture. Ecclesial movements.

\section{María en el Brasil contemporáneo: liberadora, carismática y pop}

\section{Resumen}

El artículo pretende visualizar algunos rostros que la Virgen María ha asumido en Brasil en los últimos 40 años. Para tal objetivo se hizo el siguiente recorte: María en la teología de la liberación; María en la renovación carismática católica. También se hace breve análisis de María en la cultura pop, análisis que, en este caso, extrapola las fronteras nacionales. Se pretende, por lo tanto, presentar como las sensibilidades teológicas y eclesiales contemporáneas, particularmente en Brasil, han interpretado simbólicamente la figura de María, tanto en el interior de la Iglesia Católica (los dos primeros casos) como fuera de ella. Por los límites impuestos a un artículo, se discute, aquí, sólo algunos casos específicos que, sin embargo, podrían servir como paradigmas. La metodología se basa en la ciencia de la religión en diálogo con la teología, y en el análisis de material devocional literario, musical e iconológico. A partir de esta metodología y del material utilizado en la investigación, es comprendido que la fe católica, en sus expresiones populares y, también, teológicas, busca, contemporáneamente, la interpretación sobre María anclada en sensibilidades que, lógicamente, en mucho deben a los contextos sociales, políticos, económicos y culturales en los que está inserta.

Palabras clave: María. Iglesia Católica. Cultura pop. Movimientos eclesiales.

\section{Introdução}

Mostra-nos, o Brasil, que a Virgem Maria, em tais plagas tropicais, ganha contornos específicos, mas que, em geral, ligam-se historicamente aos modelos tradicionais que a história da piedade cristã cultivou. O presente artigo não pretende recuar aos tempos antigos da piedade mariana no Brasil porque, se assim fosse, não poderia se esgotar em páginas. Para os fins aqui pretendidos, marco por iniciar a partir da década de 1970 a abordagem sobre a Virgem Maria na Igreja Católica do Brasil e na cultura pop, inclusive para além das fronteiras nacionais. Nomeadamente, quero mostrar inicialmente, arrancando desde este ponto histórico até os dias atuais, ${ }^{1}$ a Maria brasileira em duas

\footnotetext{
1 A chamada religiosidade popular tradicional não será analisada aqui, ou pelo menos não será considerada como já o foi em várias obras pretéritas e abundantes de teólogos, sociólogos e antropólogos. Ou seja, compreendo que tal religiosidade popular, hoje, se amalgama, se confunde e está presente transversalmente tanto nas formas da piedade
} 
de suas faces mais conhecidas: a da teologia da libertação e a da renovação carismática católica, ${ }^{2}$ evidenciando, entre elas, continuidades e rupturas. Evidentemente que, para os objetivos pertinentes a um artigo, não será possível um mapeamento mais exaustivo acerca das Virgens que se manifestam em ambas as sensibilidades teológicas e eclesiais. Portanto, forçoso é recortar alguns dos matizes que Maria assume em tais movimentos e, a partir deles especificamente, haurir a hermenêutica aqui postulada.

\section{A virgem libertadora}

Se há uma mãe de Jesus, no Brasil, que de certa forma liga a todos, desde a esquerda teológica e eclesiástica mais extrema, até a direita "mais católica do que o papa", 3 essa é Maria de Aparecida. ${ }^{4}$

mariana assentes à teologia da libertação, como nas formas eletivas da renovação carismática católica, isto é, as formas de piedade encontradas em ambos os movimentos podem ser, ao seu modo cada, representadas como de traço da religiosidade popular.

2 A teologia da libertação e a renovação carismática católica, como se sabe, não são movimentos monolíticos, contendo, sob a aba dessas siglas, diferentes formas de constituição e ação. Evidentemente que, nesta breve incursão, de modo algum é pretendido seccionar tais movimentos. Portanto, é forçoso que a visão, aqui contida, seja larga e generalista, sem entrar nos detalhes e rostos específicos que Maria expressa nos vários desdobramentos de tais movimentos teológicos e eclesiais. Em tempo, contudo, é possível também classificar - embora toda classificação seja, de certo modo, uma deturpação - os movimentos citados a partir da visão de sua relação e reação religiosa diante do mundo/sociedade, em que "no quadro desta nova ordem mundial, há dois papéis possíveis para ela [a teologia | religião]: terapêutico ou crítico - ou ajuda os indivíduos a funcionarem cada vez melhor na ordem existente, ou procura afirmar-se como uma instância crítica a dizer que o mundo está errado nessa ordem como tal" (ZIZEK, 2006, p. 9-10).

3 É o ditado popular, quando se diz que alguém, por ser muitíssimo católico - o que é ser "muitíssimo católico"? - é "mais católico que o papa”, como pode, também, alguém ser "mais realista que o rei", como diz a boca do povo. Claro que o citado ditado parte do pressuposto de que ser muito católico, ou ser como o papa, ou mais, é estar à direita no que diz respeito a certos elementos da teologia, do dogma e da pastoral. Mas, com a devida licença jocosa, não sei se o ditado ainda vale após a revista norte-americana Newsweek, de 10 de setembro de 2015, perguntar, em sua capa, a respeito de Francisco: "Is the Pope Catholic?". Em tempo: é verdade que tais estereótipos - direita e esquerda - sofrem de graves limitações epistemológicas e práticas, e também são muito matizados e usados, tantas vezes, de forma preconceituosa (para um lado ou para outro). Contudo, sendo a linguagem limitada também aqui, e não podendo me furtar a dizer que existem posições opostas que, uma vez constatadas, tanto em nível ideal como prático, fazem relevante diferença na vida cotidiana e nas burocracias institucionais, é necessário pontuar, ainda que de forma extremamente imperfeita e suscetível de enganos e injustiças, as tendências que se extremam, mais ou menos, para lados opostos na Igreja. Portanto, embora reconhecendo a limitação desses conceitos e da linguagem assente a eles, ainda assim é forçoso expressá-los, dado que, por exemplo, um 
A Virgem de Aparecida medeia e reconcilia - como boa mãe de família - os vários catolicismos brasileiros, isto é, o romanizador, o tradicional português, o devocional do povo, entre outros que passam sob seu olhar no vale paulista (BOFF, 1995, p. 36). Aliás, creio que o mesmo se pode dizer de muitos outros santuários e oragos marianos, surgidos ali e acolá entre os séculos. De qualquer forma, não de todos, como, por exemplo, de Fátima, em que essa mãe portuguesa tem sido, historicamente, mais bem vista pelos que são mais católicos que Francisco (com o perdão da indiscrição, caso queiramos lançar mão do dito popular já citado). Lourdes também, pelo que me consta, não chega a ser a queridinha de meios eclesiásticos mais à esquerda. Quanto a La Salette, mesmo mal existe para tais meios.

Contudo, e apesar da grande mãe mediadora que é Aparecida, Clodovis Boff (1995, p. 39) destaca, quanto a ela, a teluridade e horizontalidade na qual surge e se desenvolve o seu culto: o ambiente de tensão social, aparecendo a pobres pescadores e tomando a cor negra, dos escravos; sua devoção se inicia entre os humildes (sem o clero); o primeiro milagre foi feito a um escravo. Aqui já estamos, portanto, no centro de uma leitura que faz de Aparecida um ícone da Igreja nos meios populares ou em seu discurso libertador, a la teologia da libertação. Porém, esta leitura, penso, poderia valer, também, para tantas outras devoções na história que estão, definitivamente, mais ligadas ao povo - em sua origem e desenvolvimento - do que ao clero. Quanto à teluridade, portanto, penso que muitas das devoções marianas apresentam essa marca, ou seja, surgem da terra, do local, da aldeia, do povo, das necessidades humanas. Porém, a horizontalidade que nelas há também é sempre verticalidade, ou seja,

membro da Opus Dei dificilmente concordaria com a ordenação feminina ao ministério presbiteral, assim como um membro da organização Nós Somos Igreja provavelmente não concorda com a exclusão das mulheres da ordenação ao sacerdócio. Os exemplos, aliás, poderiam se multiplicar, embora, claro, com as imperfeições conceituais que os termos direita e esquerda comportam num universo extremamente complexo e variado como o existente na Igreja. A questão é que é possível ser de "direita" ou "conservador" em alguns assuntos (como a bioética e os direitos reprodutivos, por exemplo), e, ao mesmo tempo, ser de "esquerda" ou "progressista" em outros assuntos (como a política e a economia, por exemplo). E viceversa. Contudo, que fique claro: aqui não faço juízo de valor sobre se é mais positivo ou correto estar à "esquerda" ou à "direita", ou, se preferirem as alcunhas, ser "progressista" ou "conservador". Tais termos podem ser muito relativos e complexos, além de azeitados nos óleos de preconceitos vários, ou de estereótipos e hermenêuticas sobre a vida e a realidade ancoradas em interesses pessoais ou de grupos (afinal, costumamos ver o mundo a partir do nosso lugar e da nossa história). Para a questão mencionada, ver a excelente reflexão de Timothy Radcliffe em sua obra Ser cristão para quê? (Prior Velho: Paulinas, 2011), mais especificamente os capítulos 9 e 10. 
é sempre ela $A$ Senhora. E de tal verticalidade, talvez, a teologia da libertação se distancie um pouco quando lê o sagrado - e seus agentes - através de lentes por demais horizontalistas do que, propriamente, por meio de compreensão antropológica da relação entre o elemento humano e o sagrado. Vemos isso nos hinos marianos ligados à teologia da libertação em que a Virgem, mais que Senhora, se torna "irmã e companheira de luta".

Os hinos à Virgem gestados sob os auspícios da teologia da libertação (por exemplo, nas Comunidades Eclesiais de Base, as CEBs) são inspirados, em sua maior parte, no Magnificat, ou em seus temas conexos, conforme afirma Boff (1995, p. 77). Também Azevedo (2001, p. 137) concorda, ao afirmar que "o Magnificat constitui o locus theologicus por excelência, o texto central da mariologia da libertação". Nele Maria celebra a vitória dos pobres e a derrota dos ricos; nele as preces dos pobres são ouvidas.

Já esse primeiro dado é interessante. Muitas outras devoções marianas do passado apoiavam-se ora em passagens bíblicas - natividade, Maria aos pés da cruz (Piedade), Maria em fuga para o Egito (Desterro) -, ora em aspectos que, aparentemente, não tinham qualquer ligação com a Maria histórica, isto é, aquela retratada pelos evangelistas. Mas aqui Maria surge falando, ou seja, com a referência ao Magnificat, a teologia da libertação granjeia sua piedade mariana a partir do próprio discurso de Maria.

Os hinos marianos gestados sob a influência da teologia da libertação ou a maior parte deles - não enfatizam, por exemplo, a virgo dolorosa enquanto passiva em sua dor, mas Maria atenta às necessidades do povo e partilhando suas dores e projetos por intermédio da luta e da tomada de partido - contra e a favor. E aqui Maria toma posição. Em Fátima terá tomado posição contra o comunismo (ou, ao menos, contra os "erros da Rússia”), a julgar pelas memórias de Irmã Lúcia, e, em outras tantas aparições, terá tomado posição a favor da penitência e da oração que deveriam ser incrementadas pelos católicos. Aqui, contudo, a posição que toma é mesmo contrária, talvez, às anteriores (ou seriam complementares a elas?). Prefere tomar partido da ação político-social, da resistência e luta contra os opressores político-econômicos, e, suspeito, tem alguma simpatia por regimes à esquerda.

Na teologia da libertação Maria é a "porta-voz da revolução", companheira do povo, caminhante, e seu rosto e identidade são marcados por tons conflitivos (CAMPANHA, 1999, p. 128), em que a mulher doce dá lugar à mulher forte. Maria é identificada com as mulheres pobres em suas lutas sociais, com a operária, a sertaneja e, mesmo, com a prostituta 
(enquanto vítima da exploração sexual). ${ }^{5}$ Maria anuncia e traz o Reino de Deus (assim como a teologia da libertação o compreende) e encarna temas como caminhada, companheirismo, povo, sociedade, história, mas também agonia, aflição, eucaristia. Clodovis Boff (1995, p. 78-90) recolhe alguns hinos que, aqui, cito em fragmentos:

"Escolhida dentre os pequenos | Mãe-profeta da libertação"; "És a imagem da nova cidade | sem domínio dos grandes ou nobres"; "Vai também ao nosso lado, nesta santa Eucaristia | a companheira de luta, a Santa Virgem Maria | Guardará no coração, de seu povo a agonia"; "Vem caminhar com teu povo | de quem provaste a dor"; "Vem, Maria mulher | teu canto novo nos ensinar"; "Eu te saúdo na Mãe nordestina, mulher do sertão | Mãe campesina, operária, rosário de dor e aflição"; "Senhora de Guadalupe | Ó Virgem da Conceição | Negrinha do meu Brasil | mãe Santa da libertação”.

De certa forma - ou de toda forma? - vejo a Maria da teologia da libertação mais perto das Virgens antigas do medievo do que das Virgens aparecidas nos dois últimos séculos (refiro-me aqui, particularmente, às chamadas grandes aparições, como Lourdes e Fátima), ou seja, o que as une, a da teologia da libertação e a das devoções mais antigas, é o pé na terra, a presença na vida e nas necessidades das pessoas que ambas as Virgens encarnam, conquanto, nas duas aparições dos últimos dois séculos, parece estar, a Virgem, literalmente sem os pés na terra, a flutuar pouco acima do chão.

Analisando alguns elementos dos citados hinos, percebemos que Maria é tida como "profeta". Ora, nas aparições dos séculos XIX e XX ela também profetiza (como em La Salette e Fátima). Mas o teor das profecias é imensamente diferente. Nas aparições as profecias costumam ser sobre o fim dos tempos, a luta contra o demônio, contra os erros da Rússia, contra a lassidão religiosa, contra os erros do século liberal e racionalista. A Maria libertadora, por sua vez, traz a profecia de "uma nova cidade sem domínio dos grandes ou nobres". Mas, enfim, ambas, sempre, profecias, portanto, teleológicas, da ordem da escatologia, referentes ao fim da história, ao mundo novo, seja ele qual for. $\mathrm{E}$ assim caminha a religião: entre a saudade do paraíso e a esperança

\footnotetext{
5 Conforme relata Afonso Murad (1996, p. 20) muitas mulheres que exercem a prostituição têm grande devoção à Nossa Senhora Aparecida e, quando a noite cai, rezam para que Maria as proteja da violência e dos riscos a que estão expostas. Inclusive, ainda segundo Murad, algumas dessas mulheres homenageiam Nossa Senhora Aparecida, a 12 de outubro, levando suas filhas à festa da coroação da Virgem.
} 
da nova Jerusalém, sejam tais esperanças referentes ao jardim romântico de uma piedade desencarnada, ou ao paraíso do proletariado.

Maria, na teologia da libertação, não chora mais, mas luta; não se faz de serva ou de senhora, mas de companheira, de mulher que se mostra igual aos seus devotos na luta. Aliás, é interessante que esta palavra definidora, mulher, apareça em um dos hinos citados: "Maria mulher". Não a "Nossa Senhora", ou a "Virgem Maria", mas a mulher Maria. Claro, em todas as devoções Maria é mulher, e isto não é um detalhe: é, tal definição, uma característica simbólica que fez e faz enorme diferença para as mulheres. Mas, como é corrente dizer, a palavra tem poder. E pudor. Maria, dantes, raramente é nomeada mulher, mas aqui se diz, sem pudor, a palavra que tem poder: mulher. Antes era somente senhora e mãe, e mãe virgem. Agora é mulher, termo eivado de sentidos referentes à sexualidade, a um modo de ser no mundo. No pudor medieval, a mulher poderia ser, no máximo, mãe, e pela maternidade Maria redimia as mulheres do pecado de Eva. Agora Maria é mulher, e redime as mulheres enquanto mulheres, ou, se preferir, anuncia a chamada questão de gênero (ou é um passo para isso).

A Virgem, como dantes, continua sofrendo, mas não é mais a Virgem da piedade por Jesus - e, através dele, por todo o povo. Agora é a Virgem que guarda no seu coração a "agonia do povo". Antes a agonia de Jesus era a mediadora para Maria ser a mãe do povo agonizante. Agora Maria encarna diretamente a dor do povo, "prova" sua dor diretamente, sem que Jesus, necessariamente, suba à cena (da cruz). O povo é o meio, não mais Jesus. Isto, certamente, faz lembrar certas teorias sociais que partem do povo, não de Deus. É a crítica que Clodovis Boff fez, não sem grandes terremotos, ao método da teologia da libertação. ${ }^{6}$

Maria já não vai acima, como Senhora, mas "ao lado". Evidentemente que, na história da piedade mariana, o povo sempre pôs Maria ao seu lado, ao lado de suas necessidades (PORTELLA, 2016). Mas não era de forma a que Maria fosse interpretada como "uma igual", "companheira de luta", porém como uma mãe celeste que, efetivamente, tem poder sobre Jesus (Deus) a ponto de detê-lo, de mudar o rumo da história - pessoal ou social - a partir dos céus. Se Maria, em priscas Eras, se encarna na vida do povo, é porque está mais além, é quase uma deusa (ou o é, de fato). A sua "encarnação" não a faz "uma igual", e o assumir as dores do povo se faz a partir de sua relação

6 Clodovis Boff, Teologia da Libertação e volta ao fundamento. In: Revista Eclesiástica Brasileira (n. 268), Petrópolis, Vozes, 2007. 
privilegiada de mãe de Deus, de quem está diante de seu trono. Na teologia da libertação, entretanto, Maria está tão embaixo, tão feito carne, que pode ser saudada na "mãe nordestina, mulher do sertão | mãe campesina, operária, rosário de dor e aflição". Sem dúvida que, do ponto de vista bíblico, parece plausível tal interpretação (Mt 25,31-46). Embora que, no citado texto bíblico de Mateus, é Jesus, é Deus que se encontra nas pessoas sofredoras. Mas vá lá: onde está o Filho, está também sua mãe judia.

Também certa intimidade marca a piedade mariana na teologia da libertação. O que hoje, talvez, soasse como politicamente incorreto (racista), foi mote de hino dos idos anos 1980: "negrinha do meu Brasil". A questão da afirmação da negritude é enfatizada, particularmente associada à Senhora Aparecida. Contudo, mais que uma questão racial ou étnica, é também resgatada, na teologia da libertação, a questão cultural-religiosa ligada aos povos oprimidos negros e, assim, Maria assume rostos explicitamente sincréticos:

Senhora negra Yá querida | Senhora quilombana, Mãe de Deus Aparecida | Preta pobre Maria Mãe Yayá (...) | na partilha do amor e do Axé | companheira, guerreira, Mãe mulher (Apud CAMPANHA, 1999, p. 128).

Elementos das culturas religiosas africanas são assumidos de forma consciente, não mais de modo subliminar. Se Maria, em antanho, sempre encarnou o sincretismo em meio ao povo, agora "sai do armário", assume seu lado pancultural, seu hibridismo simbólico-cultural. O que antes era subterrâneo, agora se mostra inteiro.

Guadalupe, de certa forma, terá sido um primeiro ensaio de sincretismo assumido (e, não por acaso, Guadalupe é outro símbolo mariano da teologia da libertação). Em Guadalupe estava em questão o início de uma nova cristandade, que necessitava da renovação de seus paradigmas quando do encontro entre culturas (BOFF, 2006, p. 598). Nesse sentido Guadalupe torna-se clara mensagem: não impor uma cultura, mas, de forma dialética, construir nova cultura a partir do encontro, de modo tal que ambas se reconheçam na síntese.

Apesar de algumas arestas que já procurei explicitar, compreendo, contudo, que entre a Maria da teologia da libertação e a Virgem dos rogos de tempos passados, em alhures, há mais continuidades do que cisões. Claro que continuidades contextualizadas. Nesse sentido, remeto a partes da canção - ou ladainha - cuja beleza total só pode ser percebida quando se ouve a música: a Ladainha dos empobrecidos, de Paulo Roberto. 
(...) Mãe do criador - rogai | Mãe do salvador - rogai | Do libertador rogai por nós | Mãe dos oprimidos - rogai | Mãe dos perseguidos - rogai | Dos desvalidos - rogai por nós | (...) Mãe dos despejados - rogai | Dos abandonados - rogai | Dos desempregados - rogai por nós | Mãe dos pescadores - rogai | Dos agricultores - rogai | Santos e doutores - rogai por nós | Mãe do céu clemente - rogai | (...) Mãe dos operários - rogai | Dos presidiários - rogai | Dos sem salários - rogai por nós.

Aqui está, a meu ver, a mais pura liga entre a teologia da libertação e a tradição mariana pretérita da igreja. Não se evidencia, no hino, o mesmo recorte devocional - em continuidade - da fé medieval em Maria, mãe sobre as necessidades diárias? Não é a mesma Virgem que, hoje como ontem, em tão distantes terras e datas, rogava e roga pelos marinheiros, viajantes, parturientes, pescadores, soldados, agricultores, enfim, pela multidão?

Aqui novamente Maria é, sobretudo, mãe. Primeiramente mãe de Deus, de Jesus e, assim, mãe do povo, preferencialmente dos oprimidos, como também canta no seu Magnificat. E, de repente, desfila toda uma série de gente que, se talvez necessite de uma mulher revolucionária e lutadora ao seu lado (e eu não quero entrar no mérito de questionar a possível urgência de uma figura assim), vê, sobretudo, a necessidade de uma mãe celeste que vele sobre ela. Aqui está a Senhora da misericórdia medieval - a "mãe do céu clemente", a mater dolorosa, a que intercede e move céus e terras pelos seus. A "mãe das mães, Maria". Aqui o ícone, o símbolo que atravessa os tempos e lugares. A mãe que pode ser chamada tanto de Nossa Senhora dos Navegantes, como de Nossa Senhora dos Seringueiros.

Talvez, contudo, a maior diferença entre a mãe dos pobres, mulheres e trabalhadores de antanho, com a da teologia da libertação, é a que se refere à questão de consciência de classe. Antes Maria também era identificada como protetora de algum segmento social específico, ou de alguma causa particular. Contudo, foi o século XIX, com a revolução industrial e com o surgimento dos movimentos socialistas modernos, que viu emergir o ser humano reflexivo quanto ao seu lugar social e laboral (falo aqui a partir do conceito de "consciência de classe" forjado pelo marxismo). Nesse caso, Maria não é só a mãe dos agricultores, pescadores, desempregados, operários e boias-frias, mas também é alguém que assume o lugar desses segmentos humanos e sociais, ${ }^{7}$ ou seja, não só que roga por eles, mas

E aqui lembro o título-programa de um dos livros de Leonardo Boff, Do lugar do pobre. 
que se identifica com eles, que, numa palavra, toma consciência de classe. Conforme assinala Barnay (2013, p. 264), Maria aparece, também no século XIX, como apoiadora das "massas laboriosas como pano de fundo da chegada dos socialismos". Cita, para tanto, as devoções a Nossa Senhora das Graças, da Caridade, da Piedade ou do Bom Socorro. Também no ápice da revolução industrial, Maria manifesta-se como bom porto contra as injustiças, segundo a autora. Mas isso não em aparições ou em bricolagens criativas e arbitrárias, e sim em devoções já consagradas.

Também para Boff (2006, p. 574) Maria foi e é, na História, símbolo de resistência cultural para povos e para os pobres. E cita, entrementes, a "Carmen en la Tirana", no Chile, invocada contra o capitalismo mineiro do local; Nossa Senhora do Loreto, ou "La Negrita", em Quito, como referência de dignidade dos negros; a Virgem de Czestochowa, na Polônia comunista e do Solidarnosc, enquanto paradigma de resistência em favor das liberdades civis e políticas. E, quanto à Virgem na Polônia, era a mãe dos operários, dos pobres, mas... contra o comunismo! Lá, libertação era algo bem diferente do que os promotores da teologia da libertação latino-americana proclamam - ou proclamavam - e sonham - ou sonhavam. Mas se lá a Virgem estava do lado certo da história, é outro assunto, que não cabe a este opúsculo interrogar.

Com o desenvolvimento da teologia da libertação, Maria ganha uma amplitude de consciências que transcende o aspecto social-econômico. Já referi sobre a questão cultural, da negritude, dos povos indígenas... Mas, como de novos brotos de uma árvore já formada, foram surgindo outros ramos outrora esquecidos: a questão de gênero, a questão das chamadas minorias sexuais, a questão ecológica, entre outras. E a Virgem, assim, foi sendo tecida em malhas que, embora embrionárias na história das piedades marianas, só tiveram campo mais fecundo para desabrocharem nos contextos sociais contemporâneos.

Hoje, muito mudou. No capitalismo de economia financeira global, na sociedade tecnológica e regida pelo consumo, o oprimido e explorado já não é, somente, o operário ou o trabalhador precariamente assalariado de ontem. O que também se desenha como dramático é a exclusão. ${ }^{8}$ Ter um

\footnotetext{
Entretanto a transformação dos conceitos-palavras, neste caso, poderá correr o perigo de retirar o foco das causas da injustiça social: a exploração. Assim, se "excluído" substitui "explorado", isto não é inocente, antes sendo a remoção de uma teoria política, pois o explorado invoca uma teoria da exploração, ou seja, uma ligação entre o explorador e o explorado, entre a afluência de um e a escassez do outro. Portanto, ao se dizer excluídos, não se pretende, aqui, olvidar as relações sociais que causam a exclusão, mas, ao contrário, mais evidenciá-las.
} 
mísero emprego, de mísero salário, torna-se, por mais trágico, absurdo e injusto que isso possa soar, um "privilégio" (e, entretanto, friso as aspas). A exclusão é o fantasma mais assustador e cruel; a invisibilidade, o sofrimento pela indiferença, a completa falta de perspectivas em que a palavra "luta" já pouco significa: sobreviver já é lucro, embora com déficit. O excluído, mais que o "pobre econômico e social" antigo, é aquele que de tão miserável, por vezes já não tem mais o pão essencial, o último dos pães que torna a vida suportável e digna: a esperança, ainda que residual. Antes se podia perder o emprego, o salário, mesmo o lar. Mas perder a dignidade é a inumanidade, cujo retrato talvez mais dramático seja o do "cracudo" dos esgotos urbanos de cidades como Rio de Janeiro e São Paulo. Pessoas cujo rosto já é desfigurado de humanidade, pois nem entre os excluídos já encontram abrigo. Ainda será preciso inventar um novo e triste conceito para falar desses pós-excluídos. Mas, se é verdade que Deus tudo vê, também a estes vê e, com Ele, sua mãe também os vê.

\section{A virgem carismática}

A renovação carismática católica, por sua vez, é tão revolucionária como a teologia da libertação. A grande diferença, entretanto, é que a teologia da libertação propugna a "revolução" empírica, social, e a renovação carismática católica enfatiza a "revolução" no Espírito Santo. ${ }^{9} \mathrm{Na}$ renovação carismática católica, a figura de Maria é enfatizada como aquela que tem, em plenitude, o Espírito Santo sobre si (MURAD, 1996, p. 24) e, portanto, sendo a toda plena, ícone do ser humano completamente harmônico com Deus, sua identidade é gerida como inspiração para a perfeição cristã compreendida num viés mais espiritualizado e de moral interior. Ao menos esse é o tipo ideal - no sentido weberiano do termo - de Maria na renovação carismática católica.

Mas a renovação carismática católica não é só seu rosto institucional e burocrático. É "povo", substantivo tão dinâmico que mais parece verbo e que conceito algum consegue capturar o que seja ao certo. A teologia da libertação diz "povo"; a renovação carismática católica diz "povo"; a hierarquia diz

\footnotetext{
A teologia da libertação também parte de "revoluções" interiores, isto é, reconhece o valor fundamental da espiritualidade; mas a enfatizando como ora-ação com consequências para as mudanças das estruturas econômicas, políticas e sociais, a espiritualidade ganhou um rosto mais ligado à intervenção empírica na sociedade.
} 
"povo"; os políticos dizem "povo". ${ }^{10} \mathrm{E}$, como já demonstrou com excelência Michel de Certeau (1998, p. 95), o "povo" escapa a todos eles. Afinal:

Eles [o povo] metaforizavam a ordem dominante: faziam-na funcionar em outro registro. Permaneciam outros no interior do sistema que assimilavam e que os assimilava exteriormente. Modificavam-no sem deixá-lo.

Assim, a Virgem, também na renovação carismática católica, vai tomando rostos novos que, contudo, também têm ligação com o seu passado.

De forma geral, na renovação carismática católica - assim como em grupos tradicionalistas, contraponto dos carismáticos -, a devoção mariana é ligada a temas e formas de matriz e matiz, por vezes, pré-conciliares (refiro-me, aqui, ao Concílio Vaticano II) ou pouco enfatizadas após o Concílio, tal como o tema da escravidão a Maria, propugnado por Luís Grignon de Monfort (1673-1716), ou como a compreensão de Maria como esposa do Espírito Santo, em acordo com Maximiliano Maria Kolbe (1894-1941) (CAMPANHA, 1999, p. 150). São temas devocionais mais individualizados, psicológicos, intimistas, que procuram efetuar um laço de aliança entre o devoto e a Virgem. Entrementes, na renovação carismática católica a Virgem também está a serviço do reforço de temas ligados à moral, mas não, prioritariamente, à moral econômica ou social, mas à moral pessoal e, sobretudo, à moral referente a temas que resvalam na sexualidade. ${ }^{11}$

10 "O povo": sempre que nos referimos a ele, é na terceira pessoa. É sempre o outro e, raramente, nos incluímos nessa pequena e poderosa palavra, tanto usada e abusada. Não é caso único nas taxonomias de classe. Com "pequeno-burguês" acontece o mesmo ou ainda pior. Nesse caso, mais depressa alguém se diz como sendo "povo" do que "pequeno-burguês".

11 Por vezes, quando se fala de "moral sexual", ou da "moral da sexualidade", na igreja, pensamos imediatamente em "moralismos" - termo pejorativo - de repressão à libido, aos sentidos e aos impulsos do corpo. Contudo, é preciso dizer que, para uma visão da moral sexual que seja correta, é preciso renunciar aos dois extremos - como sempre! -, isto é, o da suspeita do corpo e o da indulgência para com ele. Conforme Timothy Radcliffe (2011, p. 141), citando a Suma Teológica do doutor angélico, "pensar que o sexo é repugnante é uma negação da verdadeira castidade e, segundo nada menos do que São Tomás de Aquino, uma imperfeição moral!”. Prossegue o dominicano: “numa ocasião em que estava a pregar sobre sexualidade, São João Crisóstomo notou que algumas pessoas coravam e ficou indignado: 'Por que coram? Não é puro? Comportai-vos como heréticos"' (Apud RADCLIFFE, 2011, p. 140). O tema é vasto e complexo, e, sem dúvida, prevaleceu (e ainda prevalece), na Igreja, o extremo da suspeita do corpo. Portanto, parece-me que a renovação carismática católica, embora com uma linguagem em moldura mais soft e clean, ainda carrega, também, essa herança histórica da suspeita. Fato é que mesmo fora do âmbito referenciado pela Igreja, ou seja, na sociedade secular, a questão da sexualidade 
Mas a moral original do povo é o pão de cada dia, seja esse o de trigo, ou o emprego, a saúde, a prosperidade. Essa moral, que a teologia da libertação procurou alcançar com seu discurso e prática, o povo a tem entendido, hoje, conforme o espírito da época (que, não necessariamente, é o Espírito Santo). E nossa época é a do consumo, da felicidade a qualquer custo, do individualismo, e, mais ainda do que no passado missionário, do "salva a tua alma", ainda que sob novas formas. A sociedade espatifou-se, os sentidos, os valores, a comunidade humana se liquefez (ZYGMUNT BAUMAN). A modernidade, que forjou o indivíduo individual (com o perdão do pleonasmo), chegou ao seu ápice, ao seu pós: agora é o salve-se quem puder. E as devoções marianas que surgem a partir da renovação carismática católica, ${ }^{12}$ mas não necessariamente sempre por meio de indivíduos conscientemente ou oficialmente ligados a ela, ${ }^{13}$ são de tal ordem que poderiam assustar a tradição devocional de uma congregada mariana.

Antes das conclusões, vamos aos fatos. Talvez uma das devoções marianas, vincadas no Brasil à renovação carismática católica, que mais tenham se robustecido - para além da sempre hors-concours Fátima - seja a de Nossa Senhora Desatadora de Nós. Tal devoção, deve-se dizer, é antiga, surgida no século XVIII, na Alemanha, e tinha, originalmente, o significado de que Maria, carregando uma corda com nós - dada por um anjo -, desfazia os nós que significavam... o pecado original e os pecados de toda a gente (ZANON, 2007, p. 99). Hoje, os pecados cederam aos problemas.

No livro A poderosa Nossa Senhora desatadora dos nós (2011), Suzel e Denis Bourgerie elencam uma série de nós e de suas respectivas orações de desata-

também é eivada de complexidade e, geralmente, vista a partir dos extremos, prevalecendo, aqui, entretanto, o extremo da indulgência, ou mesmo da banalização do corpo e do tema da sexualidade.

12 E que, para o bem da justiça, nem sempre representam a ortodoxia - caso haja alguma do pensamento oficial dos estratos institucionais e burocráticos da renovação carismática católica. Pois é, o povo...

13 Este é outro elemento importante: se é verdade que o Espírito sopra onde quer e como quer (Jo 3,8), a renovação carismática católica, enquanto movimento institucional organizado, não o controla. Afinal, “enquanto a gramática vigia pela 'propriedade' dos termos, as alterações retóricas (...) indicam o uso da língua por locutores nas situações particulares de combates linguísticos rituais ou efetivos. São indicadores de consumo ou de jogos de forças” (CERTEAU, 1998, p. 103), que não podem ser controlados. Portanto, o carismatismo, para usar esta palavra, não é mais propriedade da renovação carismática católica institucional, e suas significações e usos circulam de tal forma, e com tal liberdade, que as transmutações da piedade mariana inspiradas pelo movimento carismático parecem infinitas. 
mentos, como o nó do estupro, nós sentimentais, nó do desemprego, nó da mágoa, nó do descontrole da língua, nó da cobiça por mulheres mais jovens, entre outros. A ênfase, portanto, é no pecado individual, e, quanto a estes, privilegia os pecados morais. ${ }^{14}$ Essa é a tônica, grosso modo, das devoções marianas, cujo esteio é ou foi a renovação carismática católica. Digo ênfase, mas não exclusividade, pois o leitor atento terá reparado, anteriormente, o nó do desemprego. Mas ao contrário da teologia da libertação que, quando fala(va) de pecado - quando falava! -, referia-se, sobretudo, ao pecado estrutural, ao pecado (do) capital, a Mamon, às relações sociais e econômicas injustas como sendo o vetor do mal - e, portanto, uma abordagem coletivista, o que, claro, não é errado em teologia, pero... - , a renovação carismática católica fala do pecado da casa individual, dos sentidos desordenados, do distanciamento para com Deus, e, por vezes, de moralidades que levam a uma nova casuística revisitada, em linguagem mais $p \circ p,{ }^{15}$ mas, ainda assim, remendo novo em roupa velha.

Não se iluda, portanto, o leitor, sobre o "desemprego" que surge na citada oração da ladainha. É o meu desemprego, o meu desespero, o meu problema, e, last but not least, o desemprego enquanto fenômeno social. Isso se prova quando se encontra, nas várias manifestações cúlticas carismáticas, o povo - olhe ele aqui outra vez! - brandindo carteiras de trabalho, tentando-as encostar à custódia que o padre faz passear pela igreja (ou galpão, ou praça, ou casa de eventos, enfim...), ou, ainda, recolhendo, à carteira, a água benta aspergida pelo sacerdote.

Há, como se evidencia, íntima continuidade entre a piedade mariana na renovação carismática católica e as devoções marianas dos séculos idos. Novamente Maria é aquela que estende um braço ao devoto em suas necessidades mais prementes - sejam de ordem laboral, familiar ou sentimental - e, com o outro braço, segura a fúria divina predisposta contra o pecador. É, mais uma vez e sempre, a mãe da misericórdia, e, sob seu manto - cada vez mais largo - cabem novas formas de desamparo, desta feita às de ordem mais psicológica. Já a "moral superior" tradicional, o anseio por santidade ligado

14 Talvez também fosse interessante acrescentar a seguinte súplica: "desatai o nó que somos nós”. Se a Senhora é desatadora de nós, o principal nó, penso, é justamente nós (com o perdão do trocadilho).

15 Os exemplos são muitos mas, para ilustração, penso aqui num famoso programa televisivo da Rede Canção Nova, cujo nome é PHN (Por Hoje Não vou mais pecar). Esse programa, dirigido, em seu formato, preferencialmente aos jovens, também tem licenciado vários produtos comerciais e promove diversas atividades lúdico-evangelizadoras. 
à moral do controle dos sentimentos e instintos - particularmente aqueles do baixo ventre - ainda estão reservados, como de costume, às castas mais doutrinadas da renovação carismática católica. Para Deus, o que é de Deus: a santidade; ao povo o que é do povo: o dia de hoje, que urge redimir.

Portanto, as devoções mais em moda (sic) à Virgem - que revelam tintas carismáticas, mas que estão para além delas - são aquelas que apelam à batalha e à vitória - minha, ou para os meus - diante dos meus demônios que fecham os meus caminhos. Como se percebe, o tema da batalha e da vitória é recuperado da piedade mariana belicosa do passado. ${ }^{16}$ Mas, dantes, era um povo a lutar, uma nação, um projeto político e social que se confiava à Virgem, um ideal coletivo. Agora é a minha luta particular, a minha pequena - mas fundamental - vitória, dado que, para este mundo, que jaz sob no maligno (1Jo 5,19), já não há remédio, esperanças ou utopias. O Reino de Deus passa a ser um reino individual, ou, no máximo, que termina nos limites de meu grupo, de minha família, ou quando termina o programa televisivo de fé e o aparelho televisor se apaga.

Como na teologia da libertação, aqui também se luta, e Maria luta junto. Mas comigo! Não é mais a procissão da aldeia, da comunidade, que vai até a Virgem pedir - com festa, convívios, socializações, oferendas - pela necessidade a que aquele orago mariano representa. Sou eu - ou, no máximo meu eu alargado, a família - que vou a um local massificado do mundo urbano, em que não conheço quem está ao meu lado, fazer a minha oração pela minha necessidade. É um ato individual perdido em meio à multidão. Assim, Maria já não vela pelo povo, pela comunidade, pela aldeia, pelo grupo laboral, pelas mulheres. Ela vela por mim.

Em voga está também o culto de Nossa Senhora da Defesa, outro hit devocional contemporâneo no Brasil. Protege o menino Jesus e outro jovem desconhecido (que pode ser você ou eu) do ataque infernal. A pergunta que faço é: por que foi reapropriada a Maria da guerra, bélica do medievo, e não a do parto ou a do leite?

A linguagem da batalha espiritual, da derrota do inimigo, do amarrar Satanás, do libertar-se das maldições - temas retóricos afeitos ao universo carismático - parece sobrepor-se a um mundo simbólico mais cordial. No mundo de violência generalizada em que vivemos - mas alguma vez, na História, foi diferente? - é preciso lutar para sobreviver.

$\overline{16}$ Quanto a esse tema, as páginas 106-124 de Portella, 2016. 
Mas aqui, novamente, não é a luta de um povo ou comunidade; não é a luta dos cristãos contra os mouros, ou dos católicos contra os hereges (ou dos pobres contra os poderes opressores). A individualização das lutas mostra-nos que também a piedade mariana fica mais intimista e subjetiva. Partilham-se símbolos, iconografias e gramáticas em torno de tal piedade, mas dentro de subjetivações cada vez menos partilhadas ou assentes ao coletivo.

Com isso não quero afirmar - nem tenho autoridade ou interesse para tanto - que tais devoções, na forma em que se apresentam, estejam em desacordo com a teologia mais ortodoxa. Não! Como se pode ver na Ladainha a Nossa Senhora da Defesa, ${ }^{17}$ não há nada - julgo eu - que atente contra algum ponto da doutrina da fé. É, inclusive, ladainha bela e, a crer que a Virgem protegerá o devoto de tudo quanto ali é arrolado - talvez com uma ou outra exceção que, particularmente, eu dispensaria -, é ela muitíssimo útil e urgentemente necessária. Aliás, começa a pedir que a Senhora proteja-nos de nós mesmos, de nossos sentimentos pouco saudáveis.

Deixo aos teólogos versados na ortodoxia da fé católica a tarefa de avaliarem se pedidos de defesa contra "fracasso, objetos contaminados e superstição, frustração, heranças negativas de antepassados", que constam na ladainha, podem se alinhar ao que se crê catolicamente. Fato é que, na ladainha, surgem particularmente - como se percebe -, temas do universo psi e da moral tradicional (e casuística?) da igreja e, ambas, recaem principalmente sobre a vida atômica do indivíduo.

Maria passa na frente! Não há iconografia específica para essa devoção, sendo usadas, na maior parte das vezes, as figuras da Senhora de Fátima ou das Graças. Aqui, como outrora, continua o ser humano a pedir a proteção divina à Mãe de Deus, concedendo a ela "poder para isso" e, como para o sujeito medieval que, como vimos, bradava "se teu Filho não te ouvir, mostra-lhe os seios que o aleitaram e os braços que o carregaram", o ser humano contemporâneo continua a dizer "ninguém foi decepcionado, depois de ter invocado a tua proteção"! Ora bem, não foi também a própria Virgem que em tantas aparições nos últimos duzentos anos não se cansou de dizer isso, ou seja, não decepcionar quem se coloca sob sua proteção? Ela é porteira, tem a chave do coração de Jesus, seu Filho.

Maria, aqui, é associada a elementos da cultura e religiosidade popular que fazem referência aos caminhos e portas. ${ }^{18}$ Abrir caminhos...! Isto não

\footnotetext{
17 Quem tiver interesse poderá consultá-la em http://www.arcanjomiguel.net/senhora defesa. html (Acesso em 9 de setembro de 2016).

18 A associação de Maria com a porta é antiga e já consta na Ladainha Lauretana.
} 
lembra traços da cultura religiosa africana no Brasil, ou mágica? Já o fato de nomear a novena de "Poderosa novena" diz muito sobre expectativas, concepções de eficácia - algo que concerne, ma non troppo, ao domínio da magia - e da visão que se tenha sobre outras novenas, à mesma mãe, que talvez a não convença demasiado. Nada muito diferente, creio, do que a piedade popular, no longo tempo de sua existência, já concedeu a Maria.

Não sendo o objetivo deste artigo a análise do discurso, não é preciso demorar-se em dissertar sobre orações e textos ligados à piedade mariana, o que, como se percebe, aqui se faz com parcimoniosa economia. Apenas anoto, portanto, algumas palavras sobre a "poderosa" novena de Maria Passa na Frente. ${ }^{19}$ Em nove dias clama-se, a Maria, para que passe na frente da "minha vida", da "minha saúde", "do meu trabalho", "das minhas finanças", "da minha casa", "da minha família", "dos meus afetos e relacionamentos", "da minha fé" e "dos meus impossíveis". É a religião do pronome possessivo.

É evidente que, mesmo que não me caiba julgar sobre a ortodoxia da fé em tal oração, demonstra, a novena, fidelidade ao que há de mais santo e, mesmo, altruísta. Começa por pedir que Maria ajude a pessoa a ser um indivíduo melhor em vários quesitos, inclusive em sua vida de fé. E, quando se refere à casa e à família, pede inclusive pelos animais domésticos. Também roga por luz aos inimigos (muitos salmos bíblicos e orações pretéritas não tinham a mesma caridade para com os inimigos).

É importante referir que as orações, ladainhas, novenas que deitam suas raízes na renovação carismática católica e, mesmo, que a ultrapassam, tendem a ser holísticas, a ver integralmente o sujeito e a rogar por suas várias dimensões, seja na vida afetiva, relacional, psíquica, social, comunitária, eclesial, econômica... E, assim, não só não distam da sensibilidade mariana de tempos idos, que envolvia as necessidades de grupos humanos e sociedades, mas, inclusive, a alarga. Mas, se a alarga, o faz a partir do "eu", e não do "nós". Já não é mais o mundo, a sociedade, a pátria, o trabalho, a família que estão na ponta, e o indivíduo, por sua vez, subsumido em tais realidades. Agora as realidades, todas elas, estão subsumidas ao indivíduo, são "rezadas" a partir e para o bem-estar do indivíduo. As sociedades antigas não conheciam o indivíduo atômico. O senso coletivo de comunidade, de clã, de aldeia preponderava, em antanho, sobre o indivíduo em suas subjetividades. O indivíduo, como ser

19 A novena pode ser consultada em http://www.teologiacatolicainterativa.com.br/maria-m\%C3\%A3e-da-igreja-a-imaculada/maria-passa-na-frente/ (Acesso em 9 de setembro de 2016). 
individual (com o perdão do pleonasmo), é fruto da modernidade, e tal sintoma se "agrava" na hipermodernidade. Agora o en é o centro, e tudo o mais orbita à sua volta. ${ }^{20}$

É, contudo, muito interessante reparar que a sexualidade, na novena, é trazida à tona, nomeada, essa palavra que tanto rubor causou e causa historicamente - na igreja, ao menos dita assim, à luz do dia e em prece à Virgem. Se dantes, para ser piedoso, era preciso calá-la, agora a dita cuja faz parte da própria piedade. Claro, não pensem os mais apressados que isso queira dizer maior flexibilidade em se abordar temas ligados a esse conceito. O conteúdo sobre a sexualidade continua, grosso modo, o mesmo. O que muda é que se nomeia a antiga serpente, proscrita das pias orações e conversações religiosas. A sexualidade é assumida como um dom de Deus a ser corretamente preservado e que, para tanto, vale a pena rezar. Também a linguagem sobre ela torna-se menos pesada, ou, ao menos, matizada com tintas menos fortes.

Enfim, muito do que outrora era visto com suspeita por certas piedades é agora redimido, como o lazer. Também uma ajuda dos céus à forma física ("Para que meus ossos e minha musculatura ganhem o sopro da vida") pode se unir às atividades na academia de ginástica. $\mathrm{O}$ corpo redimido! $\mathrm{E}$ por que não alguma ajuda para passar em um concurso público ("Dos meus concursos, testes e entrevista que fiz e farei"). Não, não ajude a todos, mas os "meus" concursos, testes e entrevistas. Afinal, muitos são os chamados, e poucos os escolhidos! Por fim, é claro, estão os "impossíveis". Afinal, não foi o anjo que declarou à Virgem que para Deus não há impossíveis (Lc 1,37)?

Veja bem, caro leitor: eu considero mui linda a citada novena e, certamente, mui útil se a Senhora em tudo nos, digo, me abrir as portas requeridas e estiver à frente de tudo que sou e que me envolve. Não pretendo julgar a novena por um suposto lado psicológico, talvez até patológico, de uma extrema dependência mariana em tudo, em que minhas responsabilidades e decisões pessoais tendem a ficar mitigadas. Também não imputo algum fumo de heresia a esta ou aquela palavra ou parte da novena (creio, mesmo, que, além de bela, é de todo ortodoxa, com a vênia de, talvez, algum pormenor). O que apenas ouso afirmar é quem está no centro desta oração: o indivíduo pós, ou hiper, moderno. Um mundo que, cada vez mais, responde pela palavra eu. E Maria, claro, é também chamada a dar o seu fiat voluntas tua a esse admirável mundo novo.

20 Já não se roga por uma sociedade mais justa, mas pelas minhas finanças. 


\section{A virgem pop}

Neste cenário atual, tão afeito ao espírito pós-moderno, Maria se torna, a um tempo, grande e banal, devido à massificação de seu culto e do consumo que se faz dele, a ponto de alguns pesquisadores se perguntarem se, em um santuário como o de Aparecida, as mercadorias foram criadas para Maria ou se Maria foi feita para vender mercadorias (SANTOS, 2005, p. 250). Penso que aqui, de fato, está a mão dupla paradoxal da grandiosidade e da banalidade, muitas vezes intrincada naquilo que cresce demasiado. Mas, se Maria justifica o consumo e é consumo, ainda que banalizado, é porque sua significação também se inscreve na trivialidade do dia a dia. E, assim, não foge ela aos padrões de antanho, em que se encarnava na vida, necessidades e esperanças das pessoas, com a diferença de que não havia, em épocas remotas, produção em série e sociedades de consumo como as que conhecemos hoje. Entretanto não é verdade que, em certos períodos de antanho, o comércio de relíquias - como o do leite de Maria, de suas lágrimas, de fios de seus cabelos - era abundante? Cada época com aquilo que é seu!

Entrementes Maria, hoje, já não é propriedade dos cristãos, da igreja ou dos católicos. Na pós-modernidade as religiões passam a ser, também, como que "caixas de ferramentas simbólicas" disponíveis a todos, que tomam por empréstimo elementos das tradições religiosas já existentes e os ressignificam conforme as várias subjetividades ou experiências que se queira produzir com eles (HERVIEU-LÉGER, 1997, p. 44). Maria, portanto, sai do circuito estritamente religioso e devoto e passa a figurar - literalmente - em experimentos da arte $p \circ p$ que fazem releituras criativas do evento Virgem Maria. Para Menezes (2005, p. 26), “os santos são, ou melhor, estão fashion”, e Maria não foge à regra.

É verdade, porém, que esse desenraizamento de Maria em relação aos vínculos especificamente religiosos não é novo e, ao seu modo, existiu em diferentes épocas. E, frise-se também, ainda que tais imagens não explicitamente ligadas à igreja existissem e existam, estão elas ligadas às diversas formas de pessoas e grupos vivenciarem, fora dos certames eclesiásticos, a sua fé - ou a simpatia, a empatia, a sensibilidade - mariana.

No Brasil, como reza o ditado popular, tudo acaba em samba e, portanto, Maria também entrou na avenida. Talvez a apropriação dos elementos sagrados por instâncias de uma festa tão telúrica como a do carnaval brasileiro seja um ícone dessas "estreias" contemporâneas de Maria longe dos altares. Nos enredos de carnaval, bem como em adereços e carros alegóricos de escolas de samba, Maria costuma aparecer como destaque. Assim a Unidos do Peruche, 
Unidos de Vila Maria, Leandro de Itaquera, Águia de Ouro, todas de São Paulo, já fizeram referência a Maria em seus carnavais, bem como, no Rio de Janeiro, a Beija-Flor, Unidos de Vila Isabel e Unidos da Tijuca, sendo que, no caso do Rio de Janeiro, imagens da Virgem conseguiram ser vetadas, total ou parcialmente, por intervenção da Arquidiocese (CORDEIRO; RANGEL, LUÍS, 2013, p. 220s.). Vale destacar, ainda, o samba imortalizado na voz de Clara Nunes, "Portela na Avenida" (composição de Mauro Duarte e Paulo César Pinheiro), ${ }^{21}$ uma verdadeira pérola, pois que comporta poética simbiose entre a religião e a vida do povo.

Mas, finalmente, chamo atenção, aqui, para os ícones de Maria que ultrapassam - embora nelas se assentem - as tradicionais piedades marianas ocorridas entre os séculos. As imagens da artista francesa Soasig Chamaillard, falam por si, mas merecem uma ou outra palavra.

Figura 1. Maria rockstar, por Soasig Chamaillard. ${ }^{22}$

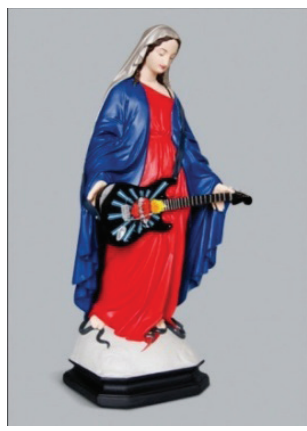

Alça do sutiã aparecendo e, ao invés do Rosário, a guitarra estampada com o sagrado coração. Maria é fashion, demonstra sex appeal e fala a linguagem cultural das novas gerações, em que a performance reina absoluta. Afinal, não é verdade que as bandas católicas de rock se multiplicam? E que o tempo das anáguas e véus sequer existe na lembrança das novas gerações?

21 Letra do samba disponível em: http://letras.com/clara-nunes/82991/ (Acesso em 1º de setembro de 2016).

22 Imagem gentilmente cedida pela artista francesa Soasig Chamaillard, e disponível em soasig-chamaillard.com. 
Figura 2. One, por Soasig Chamaillard. ${ }^{23}$

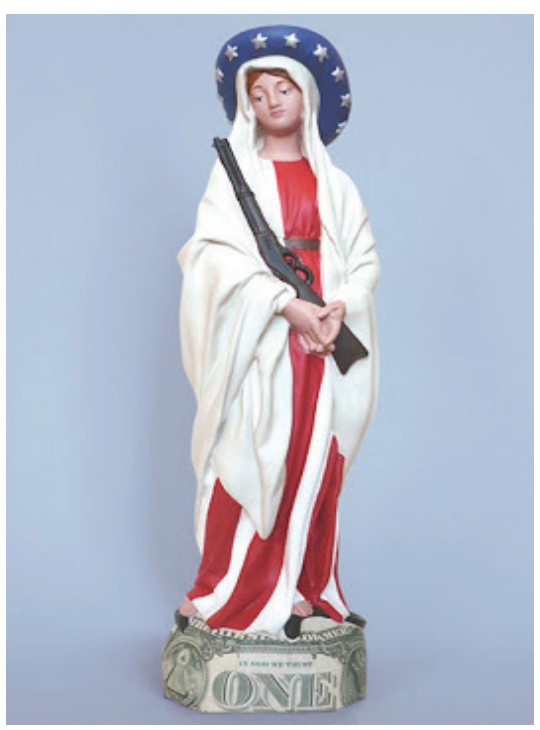

Nossa Senhora da Vitória, revisitada? Aqui a "arma" do Rosário é traduzida à vera. Está a proteger certas nações (e seus patrimônios, representados pela nota que, piedosamente, reza in God we trust). Veste-se com o pavilhão que defende. Nossa Senhora da Atalaia!! Em um país que cultua as armas, como Maria poderia ficar indiferente a essa índole civilizacional?

Figura 3. Barbie como Nossa Senhora de Fátima, dos artistas argentinos Pool e Marianela. ${ }^{24}$

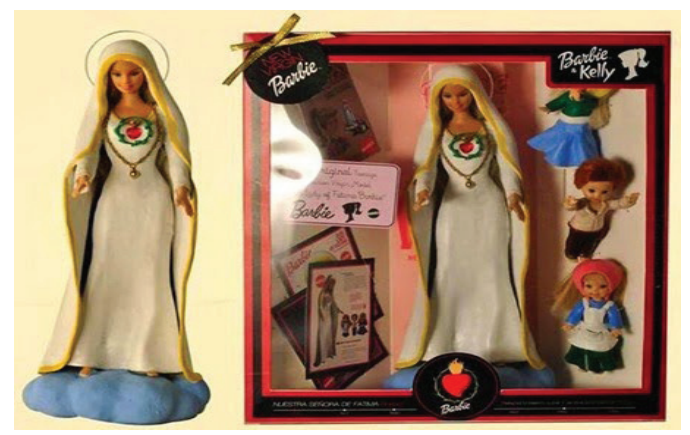

Você já entrou em uma dessas lojas que vendem objetos religiosos? Maria está nas camisetas, nos brincos, nos vestidos... Por que não estaria entre as bonecas? Uma imagem de gesso não é, de certo modo, um boneco? Mas

23 Imagem gentilmente cedida pela artista francesa Soasig Chamaillard, e disponível em soasig-chamaillard.com.

24 Imagem gentilmente cedida pelos artistas argentinos Pool e Marianela, e disponível em poolymarianela.com. 
note: é a Barbie, a mulher símbolo do mundo infanto-juvenil de tantas meninas modernas. A mulher bem-sucedida, branca, magra, rica, poderosa, enfim, bela para os padrões vigentes na maior parte das sociedades. A religião passa, também, ao mundo do lúdico: brinca-se de religião. Se, na pós-modernidade, experimenta-se religião, para perceber qual a melhor para mim, neste momento por que não brincar de religião, brincar de Deus (ou de Virgem Maria)? Assim experimentamos a História e a recriamos. E a recriaremos, claro, a partir dos padrões da indústria do belo, do lúdico e do socialmente bem aceito.

As imagens anteriores parecem iconoclastas, isto é, não pretendem ser a representação da Virgem a partir de seus contextos primários e originais, da teologia, piedade e devoção cristãs, mas, justamente, pretendem a quebra dos modelos de tais contextos, ${ }^{25}$ no espírito do desconstrucionismo. Portanto, mais que obras artísticas - que também são - ou de apelo comercial, seriam representações que se alimentam de símbolos de uma fé para a construção de performances artísticas que se encontram descompromissadas com a fé, ao menos aquela referenciada pela igreja e pela piedade popular. Buscam-se nas tradições e instituições religiosas elementos de crença e símbolos que tenham ou deem algum sentido, porém:

...a partir da subjetividade de experiências, sem fidelidades a identidades fixas, ultrapassando fronteiras antes bem delimitadas e borrando-as. Cada vez mais estes (micro) cosmos - de sínteses ou fragmentos - (...) [tomam] por empréstimo elementos das tradições religiosas já existentes, numa seletiva escolha daquilo que funciona e faz sentido (PORTELLA, 2008, p. 38).

Como Maria faz sentido para pessoas desenraizadas da religião cristã institucional? Sim, pois é possível não estar ligado, em fé e prática, a determinada religião e, ainda assim, seus símbolos se mostrarem significativos a partir de outros significados que não os originários de suas matrizes tradicionais religiosas. A cultura pop pós-moderna, portanto, que se quer, em boa medida, liberta e livre de compromissos éticos, estéticos e normativos, religiosos ou não, elabora os elementos religiosos - que carecem de patente formal - ao seu modo e gosto criativo, fazendo-os coincidir com formas de sociabilidade e de imaginação que não pedem o nibil obstat da igreja ou das tradições religiosas em geral. ${ }^{26}$

25 Eikon (ícone) + klastein (quebrar), quebrar imagens.

26 O que muitas vezes, evidentemente, é fonte de conflitos com a igreja que, com ou sem razão, considera-se a legítima depositária de certos símbolos e de sua gestão. 


\section{Considerações finais}

O cenário descrito, sobre a cultura pop, parece-me não estar muito longe da piedade popular, que sempre soube ver e "usar" - e (re)criar - os símbolos religiosos a partir de seus contextos e necessidades específicas, fazendo-os operar, muitas vezes, em chaves distintas das cridas e "usadas" pela igreja institucional. Como vimos, a renovação carismática católica também tem sido inventiva em suas interpretações sobre Maria, bem como, a teologia da libertação, isto é, a interpretam sob os novos códigos culturais, societários, teológicos ou mesmo ideológicos presentes a cada época e a cada grupo humano. Contudo, é preciso apontar, nesta comparação, uma diferença fundamental: a piedade popular - e a teologia ilustrada - sempre interpretou e vivenciou os símbolos religiosos a partir da fé - e das matrizes da fé católica - ainda que tal fé nem sempre coincidisse - no caso da piedade popular, particularmente -, em ortodoxia e prática, com a preconizada pela instituição igreja. Enfim, a piedade popular - e a teologia - vivencia e reinterpreta os símbolos cristãos a partir de dentro da fé cristã. É o povo cristão, nesse sentido, o legítimo depositário de tais símbolos. E isso faz uma diferença enorme, ou seja, a legitimidade e o valor da arte não deveriam ser banalizados pelo interesse comercial ou pela subjetividade que, em sua liberdade, tudo submete a si. Contemplar Maria é mais do que um ato que pode ser subsumido, simplesmente, a tais critérios externos à fé. Contemplá-la é professar a fé! ${ }^{27}$ A arte sobre os símbolos da fé, certamente, existe e pode existir sem a fé, mas corre o risco de perder, assim, seu fundamento original: re-velar o sagrado!

\section{Referências}

AZEVEDO, Manuel Quitério de. O culto a Maria no Brasil. História e Teologia. Aparecida, Santuário, 2001.

BARNAY, Sylvie. Aparições da Virgem. In: VAUCHEZ, André. Cristianismo. Dicionário dos tempos, dos lugares e das figuras. Rio de Janeiro: Forense Universitária, 2013, p. 25s.

BOFF, Clodovis. Maria na cultura brasileira. Aparecida, Iemanjá, Nossa Senhora da Libertação. Petrópolis: Vozes, 1995.

Para a pintura dos ícones bizantinos, nas Igrejas Ortodoxas, o artista, via de regra, deveria passar por um processo de preparação espiritual e técnica. Os ícones não são considerados apenas imagens, mas imagens literalmente sagradas, isto é, habitadas pelo poder sagrado, revelando-o aos que as contemplam. 
BOFF, Clodovis. Mariologia social. O significado da Virgem para a sociedade. São Paulo: Paulus, 2006.

CAMPANHA, João Aroldo. Maria na América Latina antes e depois do Concílio Vaticano II. Devoção-Teologia-Magistério Episcopal. Dissertação de Láurea. Roma, Pontifícia Faculdade de Teologia São Boaventura (Seraphicum), 1999, 197 fls.

CERTEAU, Michel de. A invenção do cotidiano. Artes de fazer, vol. 1. Petrópolis: Vozes, 1998. CORDEIRO, José, RANGEL, João, LUÍS, Denílson. Aparecida. Devoção mariana e a imagem padroeira do Brasil. São Paulo: Cultor de Livros, 2013.

HERVIEU-LÉGER, Danièle. Representam os surtos emocionais contemporâneos o fim da secularização ou o fim da religião? In: Religião e Sociedade, 18/1, 1997, p. 31-48.

MENEZES, Renata de Castro. Uma visita ao catolicismo brasileiro contemporâneo: a bênção de Santo Antonio num convento carioca. Revista USP, São Paulo, n. 67, set.-nov., 2005.

MURAD, Afonso. Quem é esta mulher? Maria na Bíblia. São Paulo: Paulinas, 1996.

PORTELLA, Rodrigo. A religião na sociedade secularizada: urdindo as tramas de um debate. In: Numen, Revista de Estudos e Pesquisa da Religião, Juiz de Fora, UFJF, vol. 11, n. 1 e 2, 2008, p. 33-53.

PORTELLA, Rodrigo. Mirar Maria. Reflexos da Virgem em espelhos da história. Aparecida: Santuário, 2016.

RADCLIFFE, Timothy. Ser cristão para quê? Prior Velho: Paulinas, 2011.

SANTOS, Lourival dos. A família Jesus e a Mãe Aparecida: história oral de devotos negros da Padroeira do Brasil (1951-2005). Tese de Doutorado em História Social, São Paulo, FFLCH - Universidade de São Paulo, 2005, 276 fls.

ZANON, Darlei. Nossa Senhora de todos os nomes. Orações e história de 260 títulos marianos. São Paulo: Paulus, 2007.

ZIZEK, Slavoj. A marioneta e o anão. O cristianismo entre perversão e subversão. Lisboa: Relógio D’Água, 2006.

Submetido em: 30-3-2017

Aceito em: 16-4-2018 